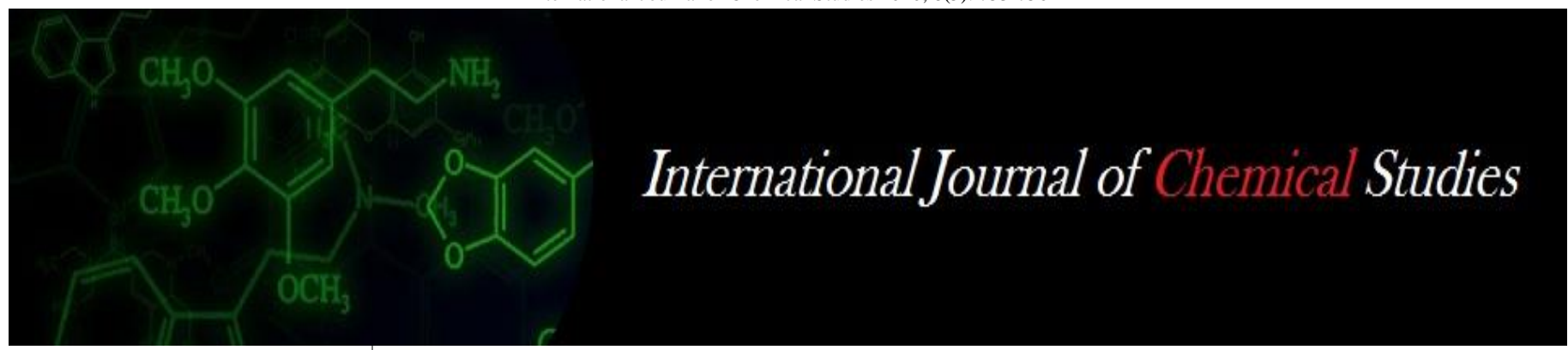

P-ISSN: 2349-8528

E-ISSN: 2321-4902

www.chemijournal.com

IJCS 2020; 8(5): 753-756

(C) 2020 IJCS

Received: 04-07-2020

Accepted: 06-08-2020

Ankur Shukla

M.Sc. Agronomy IFTM

University, Moradabad,

Uttar Pradesh, India

Raghvendra Singh

Young Professional, KVK Basuli

Mahrajganj, Uttar Pradesh,

India

Sandeep Kumar Singh

M.Sc. Agro Meteorology

ANDUAT Kumarganj Ayodhya,

Uttar Pradesh, India

Shivanand

Research Scholar Agronomy

ANDUAT Kumarganj Ayodhya,

Uttar Pradesh, India

Dev Mani Shukla

M.Sc. Biochemistry CSAU

Kanpur, Uttar Pradesh, India

Ram Singh

M.Sc. Agro meteorology

ANDUAT Kumarganj Ayodhya,

Uttar Pradesh, India

\section{Study the effect of boron levels on yield attributes of rice crop}

\author{
Ankur Shukla, Raghvendra Singh, Sandeep Kumar Singh, Shivanand, \\ Dev Mani Shukla and Ram Singh
}

DOI: https://doi.org/10.22271/chemi.2020.v8.i5k.10389

\begin{abstract}
The present study entitled "Response of Boron Levels and Application Methods on Growth and Yield of Rice (Oryza sativa L.)" in north- western plain zone of India was carried out at School of Agricultural Science and Engineering, IFTM University, Moradabad in 2018-19. The ten treatments $\mathrm{T}_{1}=100 \% \mathrm{RDF}$ $\left(150: 60: 40 \mathrm{~kg} \mathrm{ha}^{-1}\right) ; \mathrm{T}_{2}=100 \% \mathrm{RDF}+0.5 \mathrm{~kg} \mathrm{~B} \mathrm{ha}^{-1}(\mathrm{SA}) ; \mathrm{T}_{3}=100 \% \mathrm{RDF}+0.5 \mathrm{~kg} \mathrm{~B} \mathrm{ha}(\mathrm{SA})+0.2 \%$ $\mathrm{B}$ spray at $25 \& 50 \mathrm{DAT} ; \mathrm{T}_{4}=100 \% \mathrm{RDF}+0.5 \mathrm{~kg} \mathrm{~B} \mathrm{ha}^{-1}(\mathrm{SA})+0.3 \% \mathrm{~B}$ spray at $25 \& 50 \mathrm{DAT} ; \mathrm{T}_{5}=$ $100 \% \mathrm{RDF}+1.0 \mathrm{~kg} \mathrm{~B} \mathrm{ha}^{-1}(\mathrm{SA}) ; \mathrm{T}_{6}=100 \% \mathrm{RDF}+1.0 \mathrm{~kg} \mathrm{~B} \mathrm{ha}^{-1}(\mathrm{SA})+0.2 \% \mathrm{~B}$ spray at $25 \& 50 \mathrm{DAT}$; $\mathrm{T}_{7}=100 \% \mathrm{RDF}+1.0 \mathrm{~kg} \mathrm{~B} \mathrm{ha}^{-1}(\mathrm{SA})+0.3 \% \mathrm{~B}$ spray at $25 \& 50 \mathrm{DAT} ; \mathrm{T}_{8}=100 \% \mathrm{RDF}+2.0 \mathrm{~kg} \mathrm{~B}^{-1}$; $\mathrm{T}_{9}=100 \% \mathrm{RDF}+2.0 \mathrm{~kg} \mathrm{~B} \mathrm{ha}^{-1}(\mathrm{SA})+0.2 \% \mathrm{~B}$ spray at $25 \& 50 \mathrm{DAT} ; \mathrm{T}_{10}=100 \% \mathrm{RDF}+2.0 \mathrm{~kg} \mathrm{~B} \mathrm{ha}^{-1}$ $(\mathrm{SA})+0.3 \%$ B spray at $25 \& 50$ DAT combination were tested in randomized block design (RBD) with three replication.

$\mathrm{T}_{10}$ observed significant increase in all yield attributes viz., no. of tillers per $\mathrm{m}^{2}$ area, panicle length $(\mathrm{cm})$, number of filled grain panicle ${ }^{-1}$, number of unfilled grain panicle ${ }^{-1}, 1000$ - seed weight $(\mathrm{g})$, grain yield (q $\left.\mathrm{ha}^{-1}\right)$, biological yield $\left(\mathrm{q} \mathrm{ha} \mathrm{h}^{-1}\right)$ and harvest index respectively, over rest of the treatments. In $\mathrm{T}_{10}$ treatments significantly increased the no. of tillers $\mathrm{m}^{2}$ area $(199.65,210.70,212.50$ and 213.15) 30, 60, 90 and harvest stage, fresh weight $\left(66.79 \mathrm{~g}, 147.50 \mathrm{~g}, 163.00 \mathrm{~g}\right.$ and $\left.163.05 \mathrm{~g} \mathrm{plant}^{-1}\right)$ at $30,60,90$ and harvest stage, panicle length $(31.55 \mathrm{~cm})$, number of filled grain panicle ${ }^{-1}(191.20)$, number of unfilled grain panicle ${ }^{-1}$ (20.80), biological yield $\left(7.7 \mathrm{t}, 10.5 \mathrm{t}\right.$ and $\left.18.1 \mathrm{t} \mathrm{ha}^{-1}\right)$ and harvest index (42.26\%) respectively.
\end{abstract}

Keywords: Response, boron, tillers, filled, penicle, biological

\section{Introduction}

Rice is the important staple food crop for more than two third of the population of India. The slogan 'Rice is life' is most appropriate for India as this crop plays a vital role in our national food security and is a means of livelihood for millions of rural households. Rice belongs to family graminaceae or grass family.

World's food security is under threat due to the stagnated or stunted yields as main staple food crops. Rice (Oryza sativa L.) is one of the most important field crops after wheat in the world providing staple food to the millions. It is an indispensable source of calories for almost half of the population with in Asia. More than $90 \%$ of the world rice is produced and consumed in Asia, which is a native for $60 \%$ of the earth's population. Rice is the first most important crop in India where it is grown in an area of 43.9 million $^{-1} \mathrm{a}^{-1}$ with a total production of 106.77 million tonnes and an average productivity of $24.32 \mathrm{q} \mathrm{ha}^{-1}$ (Anonymous, 2015) ${ }^{[4]}$. Uttar Pradesh ranks second after West Bengal where the total production is 14.41 million tonnes with a share of $13.80 \%$ to total rice production in the country (Anonymous, 2014) ${ }^{[3]}$.

India has the largest acreage under rice i.e. 44 million hectares, with a production of about 141 million tones and the national productivity of $3.21 \mathrm{t} \mathrm{ha}^{-1}$. The burgeoning population of our country may stabilize around 1.4 and 1.6 billion by 2025 and 2050, requiring annually 380 and $450 \mathrm{mt}$ of food grains respectively (Yadav et al. 2009) ${ }^{[25]}$.

Boron (B), a non-metal micronutrient, is essential for normal growth and development of Rice crop (Dunn et al. 2005) ${ }^{[7]}$. Boron deficiencies occur over a much wider range of soils and crops in comparison to any other micronutrient deficiency. Boron deficiency has been reported in 80 countries and for 132 crops around the world. Soil orders with prevalent B deficiency are ultisols, lithic inceptisols, lithic fluvents, alfisols, psamments, oxisols, spodosols and andepts.
Corresponding Author: Ankur Shukla

M.Sc. Agronomy IFTM

University, Moradabad,

Uttar Pradesh, India 
Boron plays a major role in plant vital activities such as cell division, leaf and flower bud formation, glucose metabolism and hydrocarbons and their transport, root growth, cell wall formation and material transportation between cells. Boron transport and transfer in plant is relatively low and thus its concentration in lower parts of the plant is higher. Most of boron transport is through xylem vessel. Boron is mostly concentrated in anther, stigma and ovary. According to boron effect in increasing sugar and hydrocarbons transport through phloem (Moeinian et al. 2011) ${ }^{[16]}$. It has been reported that Boron deficiency limits reproductive growth. In wheat, B deficiency causes pooranther and pollen development, low grain set and stunted growth (Rashid et al. 1994).

One of the primary functions of boron in vascular plants has been related with the cell wall structure and function. There is direct evidence for a role of boron in cross-linking of cell wall rhamnogalacturonan II (RGII) and pectin assembly showing that boron is essential for cell wall structure and function (O’Neill et al. 2004) ${ }^{[17]}$. As a result, boron has a critical role in growing tissues. Actually, boron deficiency decreases or inhibits the growth of both vegetative and reproductive plant parts (Dell and Huang 1997) ${ }^{[6]}$. Boron deficiency inhibits root elongation through the limiting of cell enlargement and cell division in the growing zone of root tips and that in the cases of severe boron deficiency, root growth is ceases leading to the death of root tips (Mahmoud 2010) ${ }^{[14]}$.

\section{Material and Methods}

The present study intitled "Response of boron levels and application methods on growth and yield of rice (Oryza sativa L.)" was conducted during kharif season of 2018, at the experimental farm of IFTM University, Lodhipur Rajput Delhi Road NH-24, Moradabad, Uttar Pradesh. The ten treatments $\mathrm{T}_{1}=100 \% \operatorname{RDF}\left(150: 60: 40 \mathrm{~kg} \mathrm{ha}^{-1}\right) ; \mathrm{T}_{2}=100 \%$ $\mathrm{RDF}+0.5 \mathrm{~kg} \mathrm{~B} \mathrm{ha}^{-1}(\mathrm{SA}) ; \mathrm{T}_{3}=100 \% \mathrm{RDF}+0.5 \mathrm{~kg} \mathrm{~B} \mathrm{ha}$ ${ }^{1}(\mathrm{SA})+0.2 \% \mathrm{~B}$ spray at $25 \& 50 \mathrm{DAT} ; \mathrm{T}_{4}=100 \% \mathrm{RDF}+0.5$ $\mathrm{kg} \mathrm{B} \mathrm{ha}{ }^{-1}(\mathrm{SA})+0.3 \% \mathrm{~B}$ spray at $25 \& 50 \mathrm{DAT} ; \mathrm{T}_{5}=100 \%$ $\mathrm{RDF}+1.0 \mathrm{~kg} \mathrm{~B} \mathrm{ha}(\mathrm{SA}) ; \mathrm{T}_{6}=100 \% \mathrm{RDF}+1.0 \mathrm{~kg} \mathrm{~B} \mathrm{ha}{ }^{-1}$ $(\mathrm{SA})+0.2 \% \mathrm{~B}$ spray at $25 \& 50 \mathrm{DAT} ; \mathrm{T}_{7}=100 \% \mathrm{RDF}+1.0$ $\mathrm{kg} \mathrm{B} \mathrm{ha}{ }^{-1}(\mathrm{SA})+0.3 \% \mathrm{~B}$ spray at $25 \& 50 \mathrm{DAT} ; \mathrm{T}_{8}=100 \%$ $\mathrm{RDF}+2.0 \mathrm{~kg} \mathrm{~B} \mathrm{ha}{ }^{-1} ; \mathrm{T}_{9}=100 \% \mathrm{RDF}+2.0 \mathrm{~kg} \mathrm{~B} \mathrm{ha}^{-1}(\mathrm{SA})+$ $0.2 \%$ B spray at $25 \& 50$ DAT; $\mathrm{T}_{10}=100 \% \mathrm{RDF}+2.0 \mathrm{~kg} \mathrm{~B}$ $\mathrm{ha}^{-1}(\mathrm{SA})+0.3 \% \mathrm{~B}$ spray at $25 \& 50$ DAT combination were tested in randomized block design (RBD) with three replication.

The data recorded in the experiment were analyzed statistically with the help of electronic calculator following the procedure for randomized block design (RBD) given by Gomez \& Gomez (1984). The standard errors of the mean were calculated in each item of investigation and critical differences (CD) at 5\% level were worked out for comparing the treatment means whenever ' $F$ ' test was found significant. The analysis of the variance table has given in the appendices. The data are illustrated with the help of diagrams wherever, felt necessary. The distribution of degree of freedom for various sources of variations is given.

\section{Result and Discussion}

The maximum number of effective tillers $\mathrm{m}^{-2}$ area of rice (179.200) respectively, was recorded with the application of $\mathrm{T}_{10}\left[2.0 \mathrm{~kg} \mathrm{~B} \mathrm{ha}{ }^{-1}(\mathrm{SA})+0.3 \% \mathrm{~B}\right.$ spray twice at $\left.25 \& 50 \mathrm{DAT}\right]$ Table-1.This may be attributed to the reason that $\mathrm{B}$ is more responsible for increasing productive tillers, enhancing productivity of tillers with all yield parameters increase. These are in conformity with those already reported by
Rashid et al. (2004 \& 2007) ${ }^{[21,22]}$ and Ahmad and Irshad (2011) ${ }^{[1]}$.

The highest panicle length of rice $(31.55 \mathrm{~cm})$ respectively, was noticed with the application of $\mathrm{T}_{10}\left[2.0 \mathrm{~kg} \mathrm{~B} \mathrm{ha}^{-1}(\mathrm{SA})+\right.$ $0.3 \%$ B spray twice at $25 \& 50$ DAT] Table-1.This may be attributed to the reason that $\mathrm{B}$ is already beneficial for improving the panicle length and directly affected. These are in conformity with those already reported by Mehmood et al. (2009) ${ }^{[15]}$ and Phonglosa et al. (2018) ${ }^{[18]}$.

Maximum number of grains panicle ${ }^{-1}$ (212.00) respectively, was recorded with the application of $\mathrm{T}_{10}\left[2.0 \mathrm{~kg} \mathrm{~B} \mathrm{ha}^{-1}(\mathrm{SA})+\right.$ $0.3 \% \mathrm{~B}$ spray twice at $25 \& 50 \mathrm{DAT}]$ Table-1.This may be attributed to the reason that $\mathrm{B}$ applied at heading or flowering stage in rice increased and better improving the number of grains panicle ${ }^{-1}$.In rice, $B$ induces panicle numbers plant ${ }^{-1}$ and reduces poor grain fertility. These are in conformity with those already reported by Lin and Zhu (2000) ${ }^{[13]}$, Ramanthan et al. (2002) [19], Rashid (2006), Ziaeyan and Rajaie (2009) [26] and Hussain et al. (2012) [9], Maximum number of filled grains panicle $^{-1}$ (191.20) respectively, were recorded with the application of $\mathrm{T}_{10}\left[2.0 \mathrm{~kg} \mathrm{~B} \mathrm{ha}^{-1}(\mathrm{SA})+0.3 \% \mathrm{~B}\right.$ spray twice at $25 \& 50$ DAT] Table-2. This may be attributed to the reason that $\mathrm{B}$ is responsible for better seed setting and illustrated significant effect on number of filled grains. In rice, B reduces panicle sterility and induces the fertility due to high pollen and anther development and pollen germination which induces the number of filled grains panicale ${ }^{-1}$ and therefore, yield. These are in conformity with those already reported by Aslam et al. (2002) ${ }^{[5]}$, Ali et al. (2016) and Rani and Latha (2017) $^{[20]}$.

Minimum number of unfilled grains panicle ${ }^{-1}$ of rice (20.80) respectively, were noticed with the application of $\mathrm{T}_{10}[2.0 \mathrm{~kg}$ $\mathrm{B} \mathrm{ha}^{-1}(\mathrm{SA})+0.3 \% \mathrm{~B}$ spray twice at $25 \& 50$ DAT]Table2.This may be attributed to the reason that B deficiency, pollen grain appears empty and induces sterility in rice and directly affected the pollen vitality. These are in conformity with those already reported by Dell and Huang (1997) ${ }^{[6]}$, Rashid et al. (2007) ${ }^{[22]}$ and Garg et al. (1979) ${ }^{[8]}$.

1000 seed weight of rice was found maximum (31.06 g) respectively, with the application of $\mathrm{T}_{10}\left[2.0 \mathrm{~kg} \mathrm{~B} \mathrm{ha}^{-1}(\mathrm{SA})+\right.$ $0.3 \%$ B spray twice at $25 \& 50$ DAT] Table-2. This may be attributed due to the reason that, B application appreciably reduced panicle sterlity and increase weight of 1000 seed and starch content. These are in conformity with those already reported by Jana et al. (2005) ${ }^{[10]}$, Rashid et al. (2006), Ziaeyan and Rajaie (2009) ${ }^{[26]}$, and Rehman et al. (2012) ${ }^{[24]}$.

The grain yield of rice was recorded maximum $\left(76.80 \mathrm{t} \mathrm{ha}^{-1}\right)$ respectively, with the application of $\mathrm{T}_{10}\left[2.0 \mathrm{~kg} \mathrm{~B} \mathrm{ha}^{-1}(\mathrm{SA})+\right.$ $0.3 \%$ B spray twice at $25 \& 50$ DAT] Table-3. This may be attributed due to the reason that, B fertilization improves paddy yields due to the reduced panicle sterility and an increased number of productive tillers, which results in higher grain yield of rice. These results are in conformity with those already reported by Khan et al. (2006) ${ }^{[11]}$, Rashid et al. (2004 and 2007) ${ }^{[21,22]}$ Ziaeyan and Rajaie (2009) ${ }^{[26]}$ and Rashid et al. $(2009)^{[23]}$.

The biological yield of rice was recorded maximum $(181.75 \mathrm{t}$ $\mathrm{ha}^{-1}$ ) respectively, with the application of $\mathrm{T}_{10}[2.0 \mathrm{~kg} \mathrm{~B} \mathrm{ha}$ ${ }^{1}(\mathrm{SA})+0.3 \%$ B spray twice at $25 \& 50$ DAT] Table-3.This may be attributed due to the grain and straw yields were recorded highest in this treatment so biological yield was increased. B is show better result for enhancing the biological yield of rice. The same findings also reported by Ziaeyan and Rajaie (2009) ${ }^{[26]}$. 
The Harvest index of rice was observed maximum (42.26\%) respectively, with the application of $\mathrm{T}_{10}\left[2.0 \mathrm{~kg} \mathrm{~B} \mathrm{ha}^{-1}(\mathrm{SA})+\right.$ $0.3 \%$ B spray twice at $25 \& 50$ DAT] Table-3.This may be attributed due to the reason that, B element increases grain yield in this treatment, this result revealed that increasing harvest index. B fertilization is playing an important role in improving the harvest index. These are in conformity with those already reported by Hussain et al. (2012) ${ }^{[9]}$ and Kumar et al. (2015) ${ }^{[12]}$.

Table 1: Number of effective tillers $\mathrm{m}^{2}$, Panicle length $(\mathrm{cm})$ and grains panicle ${ }^{-1}$ area as influenced by different levels and application methods of B.

\begin{tabular}{|c|c|c|c|}
\hline Treatments & $\begin{array}{c}\text { Number of effective } \\
\text { tillers } \mathbf{m}^{2} \text { area }\end{array}$ & \begin{tabular}{|c|}
$\begin{array}{c}\text { Panicle length } \\
(\mathrm{cm})\end{array}$ \\
\end{tabular} & \begin{tabular}{|c|}
$\begin{array}{c}\text { Number of grains } \\
\text { panicle }^{-1}\end{array}$ \\
\end{tabular} \\
\hline $\mathrm{T}_{1-\mathrm{RDF}}$ & 157.4 & 29.6 & 199.4 \\
\hline 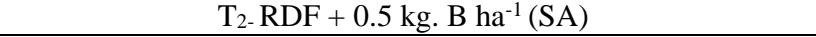 & 158.2 & 30.1 & 199.4 \\
\hline $\mathrm{T}_{3-} \mathrm{RDF}+0.5 \mathrm{~kg} . \mathrm{B} \mathrm{ha}^{-1}(\mathrm{SA})+0.2 \%$ B spray at $25 \& 50 \mathrm{DAT}$ & 158.2 & 30.2 & 195.2 \\
\hline $\mathrm{T}_{4-} \mathrm{RDF}+0.5 \mathrm{~kg} . \mathrm{B} \mathrm{ha}^{-1}(\mathrm{SA})+0.3 \%$ B spray at $25 \& 50 \mathrm{DAT}$ & 158.5 & 30.6 & 196.7 \\
\hline T5- RDF +1.0 kg. B ha ${ }^{-1}(\mathrm{SA})$ & 164.3 & 30.7 & 199.4 \\
\hline $\mathrm{T}_{6-} \mathrm{RDF}+1.0 \mathrm{~kg} . \mathrm{B} \mathrm{ha}^{-1}(\mathrm{SA})+0.2 \%$ B spray at $25 \& 50 \mathrm{DAT}$ & 167.8 & 30.8 & 199.4 \\
\hline $\mathrm{T}_{7-} \mathrm{RDF}+1.0 \mathrm{~kg} . \mathrm{B} \mathrm{ha}^{-1}(\mathrm{SA})+0.3 \%$ B spray at $25 \& 50 \mathrm{DAT}$ & 169.0 & 30.9 & 199.4 \\
\hline $\mathrm{T}_{8}-\mathrm{RDF}+2.0 \mathrm{~kg} . \mathrm{B} \mathrm{ha}^{-1}(\mathrm{SA})$ & 170.5 & 31.2 & 203.7 \\
\hline $\mathrm{T}_{9-} \mathrm{RDF}+2.0 \mathrm{~kg} . \mathrm{B} \mathrm{ha}^{-1}(\mathrm{SA})+0.2 \%$ B spray at $25 \& 50 \mathrm{DAT}$ & 175.9 & 31.3 & 211.9 \\
\hline $\mathrm{T}_{10} \mathrm{RDF}+2.0 \mathrm{~kg} . \mathrm{B} \mathrm{ha}^{-1}(\mathrm{SA})+0.3 \% \mathrm{~B}$ spray at $25 \& 50 \mathrm{DAT}$ & 179.2 & 31.6 & 212.0 \\
\hline SEm \pm & 0.27 & 0.34 & 0.16 \\
\hline $\mathrm{CD}$ at $5 \%$ & 0.81 & 1.01 & 0.47 \\
\hline
\end{tabular}

Table 2: No. of filled grain panicle ${ }^{-1}$, unfilled grain panicle ${ }^{-}$and 1000 seed weight $(\mathrm{g})$ as influenced bydifferent levels and application methods of B.

\begin{tabular}{|c|c|c|c|}
\hline Treatments & \begin{tabular}{|c|}
$\begin{array}{c}\text { No. of filled grains } \\
\text { panicle }^{-1}\end{array}$ \\
\end{tabular} & $\begin{array}{l}\text { No. of unfilled } \\
\text { grains panicle }^{-1}\end{array}$ & $\begin{array}{l}1000 \text { seed } \\
\text { weight }(\mathrm{g})\end{array}$ \\
\hline $\mathrm{T}_{1-\mathrm{RDF}}$ & \begin{tabular}{|l|l}
141.9 & \\
\end{tabular} & 57.5 & 28.9 \\
\hline $\mathrm{T}_{2}-\mathrm{RDF}+0.5 \mathrm{~kg} . \mathrm{B} \mathrm{ha}^{-1}(\mathrm{SA})$ & 148.7 & 50.7 & 29.0 \\
\hline $\mathrm{T}_{3}$ - RDF $+0.5 \mathrm{~kg} . \mathrm{B} \mathrm{ha}^{-1}(\mathrm{SA})+0.2 \%$ B spray at $25 \& 50 \mathrm{DAT}$ & 154.2 & 41.0 & 29.2 \\
\hline $\mathrm{T}_{4}-\mathrm{RDF}+0.5 \mathrm{~kg} . \mathrm{B} \mathrm{ha}^{-1}(\mathrm{SA})+0.3 \%$ B spray at $25 \& 50 \mathrm{DAT}$ & 160.3 & 36.4 & 29.5 \\
\hline T5- RDF $+1.0 \mathrm{~kg} . \mathrm{B} \mathrm{ha}^{-1}(\mathrm{SA})$ & 163.9 & 35.5 & 29.5 \\
\hline $\mathrm{T}_{6}-\mathrm{RDF}+1.0 \mathrm{~kg} . \mathrm{B} \mathrm{ha}{ }^{-1}(\mathrm{SA})+0.2 \%$ B spray at $25 \& 50 \mathrm{DAT}$ & 165.0 & 34.4 & 29.6 \\
\hline $\mathrm{T}_{7} \mathrm{RDF}+1.0 \mathrm{~kg} . \mathrm{B} \mathrm{ha}^{-1}(\mathrm{SA})+0.3 \% \mathrm{~B}$ spray at $25 \& 50 \mathrm{DAT}$ & 171.4 & 28.0 & 29.9 \\
\hline $\mathrm{T}_{8}-\mathrm{RDF}+2.0 \mathrm{~kg} . \mathrm{B} \mathrm{ha}^{-1}(\mathrm{SA})$ & 176.1 & 24.6 & 30.1 \\
\hline $\mathrm{T}_{9-} \mathrm{RDF}+2.0 \mathrm{~kg} . \mathrm{B} \mathrm{ha}^{-1}(\mathrm{SA})+0.2 \%$ B spray at $25 \& 50 \mathrm{DAT}$ & 187.0 & 24.9 & 30.2 \\
\hline $\mathrm{T}_{10} \mathrm{RDF}+2.0 \mathrm{~kg} . \mathrm{B} \mathrm{ha}^{-1}(\mathrm{SA})+0.3 \% \mathrm{~B}$ spray at $25 \& 50 \mathrm{DAT}$ & 191.2 & 20.8 & 31.1 \\
\hline SEm \pm & 0.27 & 0.49 & 0.28 \\
\hline $\mathrm{CD}$ at $5 \%$ & 0.82 & 1.45 & 0.84 \\
\hline
\end{tabular}

Table 3: Grain yield $\left(\mathrm{t} \mathrm{ha}^{-1}\right)$, Biological yield $\left(\mathrm{t} \mathrm{ha}^{-1}\right)$ and Harvest index $(\%)$ as influenced by different levels and application methods of B.

\begin{tabular}{|c|c|c|c|}
\hline Treatments & Grain yield $\left(\mathrm{t} \mathrm{ha}^{-1}\right)$ & Biological yield (t ha-1) & Harvest index (\%) \\
\hline $\mathrm{T}_{1-\mathrm{RDF}}$ & 5.4 & 14.7 & 38.8 \\
\hline $\mathrm{T}_{2-} \mathrm{RDF}+0.5 \mathrm{~kg} . \mathrm{B} \mathrm{ha}^{-1}(\mathrm{SA})$ & 5.6 & 15.2 & 39.9 \\
\hline $\mathrm{T}_{3}-\mathrm{RDF}+0.5 \mathrm{~kg} . \mathrm{B} \mathrm{ha}^{-1}(\mathrm{SA})+0.2 \% \mathrm{~B}$ spray at $25 \& 50 \mathrm{DAT}$ & 5.9 & 15.5 & 40.5 \\
\hline $\mathrm{T}_{4-} \mathrm{RDF}+0.5 \mathrm{~kg} . \mathrm{B} \mathrm{ha}^{-1}(\mathrm{SA})+0.3 \% \mathrm{~B}$ spray at $25 \& 50 \mathrm{DAT}$ & 6.0 & 15.8 & 41.0 \\
\hline $\mathrm{T}_{5} \mathrm{RDF}+1.0 \mathrm{~kg} . \mathrm{B} \mathrm{ha}^{-1}(\mathrm{SA})$ & 6.5 & 15.9 & 41.2 \\
\hline $\mathrm{T}_{6}-\mathrm{RDF}+1.0 \mathrm{~kg} . \mathrm{B} \mathrm{ha}^{-1}(\mathrm{SA})+0.2 \% \mathrm{~B}$ spray at $25 \& 50 \mathrm{DAT}$ & 6.7 & 16.1 & 41.3 \\
\hline $\mathrm{T}_{7} \mathrm{RDF}+1.0 \mathrm{~kg} . \mathrm{B} \mathrm{ha}^{-1}(\mathrm{SA})+0.3 \% \mathrm{~B}$ spray at $25 \& 50 \mathrm{DAT}$ & 6.8 & 16.3 & 41.5 \\
\hline $\mathrm{T}_{8} \mathrm{RDF}+2.0 \mathrm{~kg} . \mathrm{B} \mathrm{ha}^{-1}(\mathrm{SA})$ & 7.0 & 16.7 & 41.6 \\
\hline $\mathrm{T}_{9-} \mathrm{RDF}+2.0 \mathrm{~kg} . \mathrm{B} \mathrm{ha}^{-1}(\mathrm{SA})+0.2 \% \mathrm{~B}$ spray at $25 \& 50 \mathrm{DAT}$ & 7.3 & 17.6 & 41.8 \\
\hline $\mathrm{T}_{10-} \mathrm{RDF}+2.0 \mathrm{~kg} . \mathrm{B} \mathrm{ha}^{-1}(\mathrm{SA})+0.3 \% \mathrm{~B}$ spray at $25 \& 50 \mathrm{DAT}$ & 7.7 & 18.1 & 42.3 \\
\hline SEm \pm & 0.057 & 0.05 & 0.19 \\
\hline $\mathrm{CD}$ at $5 \%$ & 0.171 & 0.14 & 0.56 \\
\hline
\end{tabular}

\section{Reference}

1. Ahmad R, Irshad M. Effect of boron application and time on yield of wheat, rice and cotton crop in Pakistan. Soil Plant. 2011; 30(1):50-57.

2. Ali A, Zia MS, Hussain F, Khan MB. Boron requirement of rice and its management for rice production. Pakist. J Soil Sci. 1996; 11:68-71.

3. Anonymous. Pocket book on agricultural statistics 2014. Directorate of economics and statistics, department of agriculture and cooperation, ministry of agriculture, government of India, New Delhi, 2014.
4. Anonymous. Agricultural statistics at a glance 2015. Directorate of Economics and Statistics, Department of Agriculture and Cooperation, Ministry of Agriculture, Government of India, New Delhi, 2015.

5. Aslam M, Mahmood IH, Qureshi RH, Nawaz S, Akhtar J. Salinity tolerance of rice as affected by boron nutrition. Pak J Soil Sci. 2002; 21:110-118.

6. Dell B, Huang L. Physiological response of plants to low boron. Plant and Soil. 1997; 193:103-120. 
7. Dunn D, Stevens G, Kendig A. Boron fertilization of rice with soil and foliar applications. Crop Manage. 2005; 1:1-10.

8. Garg O, Sharma A, Kona G. Effect of boron on the pollen vitality and yield of rice plants (Oryza sativa L. var. Jaya). Plant Soil. 1979; 52:951-594.

9. Hussain M, Khan MA, Khan MB, Farooq M, Farooq S. Boron application improves growth, yield and net economy return of rice. Rice Sci. 2012; 19:259-262.

10. Jana KP, Ghatak R, Sounda G, Ghosh RK, Bandyopadhyay P. Effect of boron on yield, content and uptake on NPK by transplanted rice at farmer's field on red and laterite soils of West Bengal. J Inter Acad. 2005; 9:341-344.

11. Khan R, Gurmani HA, Gurmani AR, Zia MS. Effect of boron application on rice yield under wheat rice system. Int. J Agric. Biol. 2006; 8(6):805-808.

12. Kumar Narendra, Misra Ritika, Shankhdhar SC, Shankhdhar, Deepti. Effect of foliar application of boron on growth, yield, chlorophyll, amylose and nitrate reductase activity in rice. ORYZA- An International Journal on Rice. 2015; 52(2):123-130.

13. Lin $X Q, Z$ Zhu DF. Effects of regent on growth and yield in rice. Acta Agric Zhejiang. 2000; 12:70-73.

14. Mahmoud, Shaaban M. Role of Boron in Plant Nutrition and Human Health. American Journal of Plant physiology. 2010; 5:224-240.

15. Mehmood HE, Kausar R, Akram M, Shahzad MS. Is boron required to improve rice growth and yield in saline environment? Pakistan Journal of Botany. 2009; 41:13391350.

16. Moeinian MR, Zargari K, Asanpour JH. AmericanEurasian J Agric. \& Environ. Sci. 2011; 10(4):593-599.

17. O'Neill MA, Ishii T, Albersheim P, Darvill AG. Rhamnogalacturonan II: structure and function of a borate cross-linked cell wall pectic polysaccharide. Annual Review of Plant Biology. 2004; 55:109-139.

18. Phonglosa A, Dalei BB, Senapati N, Pattanayak SK, Saren S, Ray K. effect of boron on growth, yield and economics of rice under eastern ghat high land zone of Odisha. International Journal of Agriculture Sciences. 2018; 10(7):5660-5662.

19. Ramanathan S, Stalin P, Thilagavathi T, Natarajan K, Ankorion Y. Foliar nutrition of peak on rice. In: Proceeding of the 17th WCSS, 14-21 August, Thailand, 2002, 2231-2242.

20. Rani PS, Latha A. Effect of calcium, magnesium and boron on nutrient uptake and yield of rice in Kole lands of Kerala. Indian J Agric. Res. 2017; 51(4):388-391.

21. Rashid A, Yaseen M, Ashraf M, Mann RA. Boron deficiency in calcareous soil reduces rice yield and impairs grain quality. International Rice Research Notes. 2004; 29(1):58-60.

22. Rashid A, Yasin M, Ali MA, Ahmad Z, Ullah R. An alarming boron deficiency in calcareous rice soils of Pakistan: boron use improves yield and cooking quality. In: $\mathrm{Xu} \mathrm{F}$ (ed) Advances in plant and animal boron nutrition. Proc 3rd international symposium on all aspects of plant and animal boron nutrition, Wuhan, China, 9-13 Sep 2005. Springer, Dordrecht, 2007, 103-116.

23. Rashid A, Yasin M, Ali MA, Ahmad Z, Ullah R. Boron deficiency in rice in Pakistan: A serious constraint to productivity and grain quality. In: Salinity and water stress: Improving crop efficiency, 2009, 213-219.
24. Rehman A, Farooq M, Cheema ZA, Wahid A. Seed priming with boron improves growth and yield of fine grain aromatic rice. Plant Growth Regul, 2012 doi: 10.1007/s10725-012-9706-2.

25. Yadav GS, Dinesh Kumar, Shivay YS, Harmandeep, Singh. Zinc- Enriched Urea Improves Grain Yield and Quality of Aromatic Rice. Better Crops. 2009; 3:4-5.

26. Ziaeyan AH, Rajaie M. Combined effect of zinc and boron on yield and nutrients accumulation in corn. Int. J Plant Prod. 2009; 3:33-45. 